\title{
Dimensão ético-social: memória subversiva de um Deus Crucificado
}

\author{
Ethical social dimension: subversive \\ memory of a Crucified God
}

\section{Élio Estanislau Gasda*}

Faculdade Jesuíta de Filosofia e Teologia (FAJE), Belo Horizonte, MG, Brasil

\section{Resumo}

O Cristianismo contém uma dimensão social evidente e se caracteriza fundamentalmente como uma religião ética. Para desenvolver essa tese, o artigo parte de três considerações prévias: a ética sempre é social; toda reflexão teológica contém uma dimensão histórica-social; a sociedade, a academia e o Estado, como interlocutores, exigem uma postura aberta e dialogal por parte do teólogo. A partir do Evento Cristo, o texto discorre sobre conceitos nucleares da teologia: imagem de Deus, a historicidade de Jesus e a ética do Reino, a centralidade dos abandonados ao sofrimento, dimensão socioestrutural do pecado do mundo. Ora, se a origem do Cristianismo se deve à memória subversiva de um Deus Crucificado, conclui-se que uma teologia desprovida da dimensão ético-social não encontra justificação alguma na Revelação. Portanto, a dimensão ético-social da teologia cristã brota do núcleo do Mistério da Revelação.

*EEG: Doutor em Teologia, e-mail: gasdasj@hotmail.com 
Palavras-chave: Ética social. Reino de Deus. Sofrimento humano. Pecado estrutural. Cristianismo.

\section{Abstract}

Christianity contains an obvious social dimension and is fundamentally characterized as an ethical religion. To develop this thesis, the article starts from three previous considerations: ethics is always social; all theological reflection contains a historical-social dimension; the society, the academy and the State, as interlocutors, demand an open and dialogical position on the part of the theologian. From the Christ Event, the text discusses nuclear concepts of theology: the image of God, the historicity of Jesus and the ethics of the Kingdom, the centrality of the abandoned to suffering, socio-structural dimension of the sin of the world. Now, if the origin of Christianity is due to the subversive memory of a Crucified God, it follows that a theology devoid of the ethical-social dimension finds no justification in Revelation. Therefore, the ethical-social dimension of Christian theology springs from the core of the Mystery of Revelation.

Keywords: Social ethics. Kingdom of God. Human suffering. Structural sin. Christianism.

\section{Introdução}

Pode a teologia continuar impassível diante de um sistema estruturalmente violento, injusto com o ser humano e devastador para o meio ambiente? Muitos são os desafios impostos pela realidade global. Pobreza, miséria, conflitos armados, tráfico de pessoas, desemprego, crise ecológica, não são questões meramente econômicas. Elas perpassam as diversas dimensões da organização social.

A teologia é desafiada a refletir sobre a práxis, não apenas sobre os conteúdos da fé. Qual a importância sociopolítica do cristão? O Cristianismo é alienante ou libertador emancipador? A dimensão éticosocial faz da teologia uma instância crítica da presença pública da Igreja. 
Mas, qual a relevância da práxis dos cristãos em termos sociais e políticos? Até que ponto a tradição cristã coloca-se como operante na promoção dos direitos humanos, na busca do bem comum e da justiça social?

O artigo tem por objetivo oferecer elementos teóricos da dimensão ética e social, para que a presença dos cristãos seja mais significativa. Acentuar estes aspectos contribui para que a missão da Igreja seja mais integral, pois "se a dimensão social da evangelização não for devidamente explicitada, corre-se o risco de desfigurar o sentido autêntico e integral da missão evangelizadora" (EG 176). A perspectiva ético-social impede que a proposta de Jesus seja reduzida a uma tradição moral e seus textos convertidos em doutrinas que ignoram o contexto histórico e as angústias dos pobres.

\section{A ética sempre é social}

Apessoa humana é um ser histórico-relacional, é um ser de comunicação. Como um ser de relações, é um sujeito ético. Somos éticos em relação aos outros, à sociedade, ao mundo. Todo ser humano, como indivíduo históricosocial, é um ser de práxis. "Social" engloba as instituições, ações, ideologias e comportamentos com repercussão pública. As estruturas sociais se expressam em configurações históricas, culturais, políticas. A ética investiga e analisa os conteúdos destas estruturas e seu funcionamento. Não parte de abstrações, mas da realidade tal como se apresenta.

Também o Cristianismo considera a pessoa como abertura e relação. Todo ser humano é imagem e semelhança de Deus (Gn 1,27) não na individualidade fechada, mas em relação aos outros, à semelhança das Três Pessoas Divinas. A pessoa é criada como uma presença voltada para o outro e para a Criação. Humaniza-se nas relações. Não existe senão para os outros, não se conhece senão pelos outros, não se encontra senão nos outros. Aquele que se encerra no seu eu, não se humaniza. Só existe na medida em que existe com os outros. Toda pessoa é, desde suas origens, ser para (MOUNIER, 2004).

O gênero humano tem uma história e destinos coletivos, de onde não pode ser separado nenhum destino individual (BURITICA ZULUAGA, 2014). O processo de humanização se dá através da unidade interpessoal. 
A sociabilidade proporciona a conservação da raça humana. A relevância da dimensão de sociabilidade da pessoa humana imago Dei é um dos elemento fundamentais na superação do individualismo radical gerador da cultura da indiferença. A salvação não se resume a uma questão individual. "É a pessoa humana que deve ser salva. É a sociedade humana que deve ser renovada” (GS 3).

\section{Dimensão histórica-social do pensar teológico}

Se a sociabilidade é uma dimensão constitutiva da vida humana, o uso da racionalidade, a comunicação do pensamento, é um momento essencial. Consequentemente, o ato de pensar teologicamente é uma atividade constitutivamente social. Seu conteúdo trata de esferas da sociedade como a religião, as tradições culturais, o sentido e a estrutura da crença em divindades. E, no caso do cristianismo, de um Deus presente na história da humanidade. A teologia descobre e fundamenta a dimensão social na Revelação, mais especificamente, no Evento Cristo. Nele, a história recebeu uma perspectiva escatológica com implicações ético-sociais. O amor salvador de Deus está voltado para o ser humano. Teologia, sociedade e ética são faces de uma moeda. A dimensão social é inseparável da experiência de Deus. Trata-se de uma espiritualidade encarnada no contexto socioeconômico, político e cultural.

O cristianismo é uma religião pública. O maior obstáculo para fazer transparecer sua publicidade não é a secularização, mas a privatização da fé. Seus conteúdos centrais (Graça e Salvação, pecado e conversão, etc.) geralmente são assumidos como pertencentes à esfera individual. A teologia, quando ocupada unicamente com a dimensão privada da vida, torna-se irrelevante para a sociedade.

O teólogo tem grande responsabilidade no esforço de superação da fé entendida de modo puramente eclesiocêntrica e individualista. A comunidade de fé não é sua única interlocutora. A sociedade, a academia e o Estado também o são. Pode-se afirmar que a perspectiva social da teologia se fundamenta na própria pessoa do teólogo. Assim como a teologia tem uma dimensão eclesial, acadêmica e pública, também o 
teólogo é um sujeito eclesial, acadêmico e político. O teólogo é cristão, é intelectual, é cidadão (TRACY, 1981). Ele é, simultaneamente, sujeito eclesial e sujeito social. Eclesialidade e cidadania estão articuladas na mesma identidade do sujeito que reflete a realidade na ótica da fé.

Todo discurso está situado no contexto histórico do teólogo. Ainda que a realidade onde ele está inserido é mais ampla que sua reflexão, uma visão global é condição para descobrir o real sentido dos acontecimentos. Encarnar-se na realidade para ter uma visão de totalidade a partir do Evangelho. Conforme Metz (1968, p. 5)

O teólogo, diante dos problemas atuais, está numa situação difícil: possui um tesouro de verdades eternas e de santos princípios, mas não pode pagar com eles as exigências concretas da sociedade. Ainda vive de crédito, mas as dívidas da teologia crescem diariamente. O lugar onde a teologia 'pode mudar' chama-se sociedade, e as condições de mudança são as seguintes: romper o âmbito do 'privado' e baixar do céu do 'metafísico' tanto na ordem do pensamento como na da linguagem teológicos.

O que um discurso sobre Deus tem a ver com a sociedade? Por um lado, a dimensão ética possibilita a abertura do pensar teológico para a esfera social. Por outro, a consideração das diversas realidades humanas permite interpretar com mais liberdade e largueza a experiência de Deus. A ética amplia horizontes. A teologia quer compreender a história à luz da economia da salvação. Neste sentido, ela não se restringe à esfera eclesiástica e individual. Seu discurso extrapola os muros das religiões. A Teologia Negra, as Teologias da Libertação, a Teologia Feminista, a Teologia Gay, a Eco-teologia, a Bioética Teológica, a Doutrina social da Igreja, entre outras formas de discurso, ilustra de forma significativa a interlocução da teologia com a academia, a sociedade civil e o Estado.

Se o cristianismo não é uma seita, o teólogo não pode desentender-se dos assuntos sociais. A teologia cristã, por essência, é pública, porque o cristianismo é uma religião pública. Seu conteúdo, como lembra Bento XVI, tem inegáveis implicações éticas sociais:

A fé tem a sua natureza específica de encontro com o Deus vivo - um encontro que nos abre novos horizontes muito para além do âmbito próprio 
da razão [...]. Tratando-se de uma tarefa humana primária, a Igreja tem o dever de oferecer, por meio da purificação da razão e através da formação ética, a sua contribuição específica para que as exigências da justiça se tornem compreensíveis e politicamente realizáveis (DCE 28).

\section{Uma teologia que pergunta e se deixa questionar}

A nova forma de entender a relação da Igreja com a sociedade inaugurada pelo Concílio Vaticano II levou ao aggiornamento na forma de elaborar a reflexão teológica:

Depois de ter exposto a dignidade da pessoa humana, bem como a missão individual e social que está chamada a realizar no mundo, o Concílio dirige agora a atenção de todos, à luz do Evangelho e da experiência humana, para algumas necessidades mais urgentes do nosso tempo, que profundamente afetam a humanidade (GS 46).

Fidelidade ao Evangelho e fidelidade à realidade são indissociáveis. A realidade é dinâmica, plural, nebulosa, pluridimensional, em uma palavra, complexa. Esmiuçá-la é uma arte que exige sensibilidade, objetividade e honestidade. Para refletir de forma coerente um fenômeno social é necessário tê-lo compreendido de forma suficiente. Um erro na sua intepretação gera discursos teológicos frágeis, incompreensíveis e insuficientes (cf. GASDA, 2014, p. 16). Portanto, o primeiro passo consiste em aproximar-se objetivamente da realidade. Somente desta forma a releitura dos temas teológicos - Criação, Redenção, Libertação, Reino de Deus - terá alguma incidência sobre os desafios que se apresentam.

A orientação Conciliar implica reconhecer a pluralidade de discursos, sentimentos, ideologias e projetos históricos distintos. Cada esfera da existência humana contém uma racionalidade peculiar cuja autonomia deve ser respeitada. Também os interlocutores estão sob a vontade salvífica de Deus. O "desejo de unir a luz da Revelação ao saber humano para iluminar o caminho empreendido pela humanidade" (GS 33), exige diálogo interdisciplinar que contempla o saber das diversas ciências na busca da verdade da pessoa humana, do bem e da justiça. 
Quando a realidade deixa de ser uma perspectiva paralela ao Evangelho, a teologia se aproxima do ser humano concreto, do seu tempo e sua cultura.

O descompromisso com a sociedade esvazia a importância da teologia para a evangelização e a sociedade. A realidade histórica é a chave de leitura para evitar esse risco. Através dos seus membros, "[...] a Igreja se sente íntima e realmente solidária do gênero humano e de sua história" (GS 1). O cristianismo é um espírito que configura todas as ações na sociedade. A coerência entre a Teologia e práxis visa articular a seriedade acadêmica ao compromisso social dos cristãos. O discurso teológico está estreitamente vinculado à esta ortopráxis.

\section{Ética e imagem de Deus}

Todo cristão almeja contemplar o rosto de Deus (S1 27,11). A coexistência entre práxis e fé condiciona a imagem de Deus. Esta, por sua vez, condiciona os comportamentos. A teologia que transmite uma imagem de Deus abstrato, moralista e distante, tem pouco a contribuir no processo de humanização da sociedade.

O cristão revela em que Deus crê mais nas obras do que em palavras. Para mostrar ao mundo o verdadeiro rosto de Deus e a plenitude do ser humano, a ética constitui uma dimensão inseparável do Cristianismo. Neste sentido, o Cristianismo é uma religião ética. Nele, a práxis precede o labor teológico, as narrativas e teorias. A ortopráxis é mais importante do que a ortodoxia. A teologia é momento segundo. Segundo Boff (1987, p. 37), "antes de ser uma confissão, ou uma afirmação teórica, a fortiori, a transcendência da fé se relaciona com uma opção de vida, implicando práticas correspondentes. Fé é primeiramente, e acima de tudo, embora não exclusivamente, orthopraxis".

Os gestos, o estilo de vida, o ethos de Jesus mostrou ao mundo quem é Deus e quem é o ser humano. Suscitou um estilo de vida inseparável da fé e uma ética coerente com o Evangelho, o caráter crítico articulado ao conteúdo propositivo. 
A ética leva a Deus que espera uma resposta comprometida que está fora das categorias do mercado. Deus é incontrolável, não manipulável e até mesmo perigoso, na medida em que chama o ser humano à sua plena realização e à independência de qualquer tipo de escravidão (EG 54).

A teologia deve estar atenta em apresentar uma imagem coerente com a revelação que inspire uma ética igualmente coerente com a fé. A revelação da imagem de Deus e da identidade mais profunda do ser humano acontece no interior da história de um povo. A Sagrada Escritura narra Deus agindo em acontecimentos históricos, em pessoas, ideias e movimentos, nos costumes e instituições. Seus relatos mostram a criação como obra de um Deus que salva e liberta. O mesmo Deus é Criador e Libertador. Plano da criação e plano de redenção são indissociáveis. O relato do Êxodo é a sua manifestação mais explícita. A ceia de Páscoa é, acima de tudo, memorial da libertação da casa da escravidão. Fazer memória histórica é esperar a vinda da libertação definitiva.

A justiça humana está unida à justiça de Deus na história. A justiça em Israel é uma resposta a esta manifestação do amor de Deus por seu povo. Deus é o primeiro a não tolerar a injustiça e a exigir a sua correção, pois ela implica ruptura da Aliança e profanação do culto (Is 58,3-5) e demais liturgias (Am 5,21-25; 8,4-8; Is 1,11-17). Conhecer a Deus é praticar a justiça. "Teu pai comia e bebia, mas praticava o direito e a justiça e defendia a causa do pobre. Isso é o que significa conhecer-me" (Jr 22,13-16).

Conhecer a Deus não significa se engajar numa piedade particular, ou aceitar certas declarações ortodoxas, ou adorar corretamente. Falsificar essa imagem de Deus é a pior das heresias. É criar um ídolo. Não há separação entre amar a Deus e comprometer-se com a justiça social. "Eu, o Senhor, que sou o primeiro, estou com os últimos" (Is 41,4).

\section{Jesus e o Reino}

Em última análise, a dimensão social da teologia cristã se origina do Memorial de Jesus de Nazaré. Os Profetas anunciaram a vinda de um Messias que restabeleceria a justiça (Is 9,6; 11,3-5). Jesus assume essa tradição (Lc 16,19-31; Mt 6,24) e oferece a todos, mas em primeiro lugar 
aos pobres e abandonados, uma Nova Aliança com Deus (Lc 4,18-21). "Buscai em primeiro lugar o Reino e a sua justiça" (Mt 6,33). A justiça ocupa o centro do Sermão da Montanha (Mt 5,6.10.20; 6,1.33), vai além da letra da lei $(5,21-47)$ e exige misericórdia $(5,48)$. "Bem-aventurados os perseguidos por causa da justiça porque deles é o Reino dos Céus" $(5,10)$.

O mistério pascal ocupa o centro da história da salvação. A experiência da libertação sociopolítica da escravidão no Egito está na memória cristã como evento que antecipa a plenitude da redenção pela morte e ressurreição de Jesus. O conceito de memorial exprime toda esta densidade: "Fazei isso em minha memória" (Mc 14,22-25) (cf. SCHOTTROFF, 1978, p. 710-724).

A recordação deste evento histórico desperta perspectivas para a sociedade. Seu conteúdo é subversivo. Não há acesso ao Cristo da fé que não seja através de Jesus histórico. Talvez, o maior problema em acentuar a dimensão social do cristianismo seja a despolitização do Evangelho ocorrida na história da Igreja. Ocultou-se a figura histórica de Jesus como um homem público que questionou as estruturas de poder. Um Jesus despolitizado não seria condenado como rebelde. O Império romano determinava as condições de vida na Palestina. Seu poder era exercido à base de terror, violência, extorsão e cumplicidade dos líderes locais. Jesus foi executado por crucificação, uma forma de suplício que as forças de ocupação aplicavam para aterrorizar povos escravizados, torturando publicamente os subversivos até a morte (cf. HORSLEY, 2004, 34-35) ${ }^{1}$.

Os gestos e palavras de Jesus o levaram a padecer sob Pôncio Pilatos. Neste contexto situa-se o acontecimento histórico da sua condenação (cf. Mc 14,25; Lc 22,18). Sua entrega radical está no horizonte da sua missão, sua morte é muito mais do que a morte de um homem resignado a um destino traçado que ele não controla. Sua morte na cruz não foi um engano jurídico.

1 “Os romanos adotaram a crucificação como forma extremamente dolorosa de execução por tortura, aplicável principalmente a escravos insubmissos e provincianos rebeldes. Em geral, era acompanhada de outras formas de tortura, como a flagelação implacável. As crucificações eram realizadas em lugares elevados em razão de seu demonstrativo sobre a população escravizada. Os generais e governadores romanos designados para a Judeia e Galileia usavam sistematicamente a crucificação para aterrorizar a população e reprimir focos de resistência. Os romanos chamavam os rebeldes mais perigosos de bandidos" (p. 34). 
A dimensão social da teologia não procede deste ou daquele aspecto particular do Evangelho, mas da pessoa de Jesus e sua mensagem. O fundamento da dimensão ético-social da teologia encontra-se no Reino de Deus. O núcleo do discurso teológico está constituído pela mensagem central deste rebelde crucificado por ordem do Império Romano: a boa notícia aos pobres, euangélion: basileía toû Theoû (cf. Mc 1,15; Mt 5,3-12) ${ }^{2}$.

O Reino não é abstração ou puramente celestial, mas uma realidade radicalmente oposta aos mecanismos e estruturas históricas apoiadas no terror. É impossível separar a dimensão religiosa da vida político-econômica nas sociedades tradicionais. Os galileus eram profundamente politizados.

A crucificação deste subversivo impede qualquer forma de privatização da fé, é elo entre mistério da salvação e realidade humana. O povo de Deus é o sujeito histórico que vive deste memorial. A teologia do Reino de Deus é uma teologia pública. Sua dimensão social contempla as exigências de uma práxis coerente com a vida e a proposta e Jesus. Não há uma teologia que aborda o tema de Deus e "outra" que reflete sobre problemas humanos à luz da revelação. As coisas do Alto, os assuntos do Reino somente podem ser abordados a partir da realidade humana. O Reino de Deus pode estimular a sociedade a buscar modelos de organização social baseados na justiça e de instituições a serviço do bem comum. O Reino de Deus irrompe onde a justiça é restaurada.

\section{Assumir as dores dos abandonados ao sofrimento}

A característica mais destacada do anuncio do Reino de Deus é sua destinação aos sofredores e abandonados pelos poderosos deste mundo (cf. Lc 1,52-53; 4,16-19), ocupam os primeiros lugares no banquete do Reino (cf. Lc 14,13-14). A principal atividade de Jesus consistiu em combater o sofrimento humano. Por um lado, tenta eliminá-lo, pois o sofrimento do outro é intolerável. A dureza do coração causava-lhe

2 J. Moltmann reflete sobre o Deus Crucificado como base crítica da teologia cristã (MOLTMANN, J. 0 Deus crucificado: a cruz de Cristo como base crítica da teologia cristã. Santo André: Academia Cristã, 2011). Apesar das conexões possíveis, nossa abordagem não desenvolve a argumentação deste autor, mas segue outro viés, de enfoque ético-social, iluminado pela categoria Reino de Deus. 
profunda tristeza (cf. Lc 13,10-16). Por outro lado, sua paixão não é centrada em si mesma. Assumiu a figura do Servo sofredor (cf. Mt 8,17) e carregou os clamores de todos os flagelados da terra (cf. Mt 25,31-46).

Assim como contexto histórico explica a cruz de Jesus, também a teologia está condicionada por seu contexto. O discurso é formulado a partir das angustias impostas pelo contexto histórico. Os fenômenos são referenciais imprescindíveis na abordagem sobre a historicidade da Salvação. Qual a maior provocação da sociedade atual para a fé? O sofrimento, em todas as suas formas, é superabundante. A violência, a injustiça e a morte de inocentes pode ser a maior prova contra a existência de Deus. Como vincular Deus ao sofrimento dos inocentes?

O sofrimento desconcerta e pode esvaziar o anúncio do Evangelho. Como fazer teologia diante dos estarrecedores dados da fome mundial, dos genocídios e terrorismos de Estado contra pobres e negros, mulheres, gays e transexuais, povos indígenas, refugiados e imigrantes? Como um Deus impassível pode ser solidário diante de tanta violência, e desespero? Como não sucumbir ao escândalo do sofrimento do inocente? A pergunta sobre Deus é, antes de tudo, a pergunta pelo sentido, pela vida e esperança de todos os abandonados da terra (cf. METZ, 1992).

Todo discurso sobre Deus que prescinde do sofrimento é vazio, palavreado dispensável. Porque é no sofrimento que a esperança de salvação é mais urgente. Em que Deus creem as vítimas da violência? Só um Deus sofredor pode dar sentido à sua dor. A teologia cristã acredita em um Deus que sofre sem deixar de ser Deus. É o que afirma Gaudium et spes:

As alegrias e as esperanças, as tristezas e as angústias dos homens de hoje, sobretudo dos pobres e de todos aqueles que sofrem, são também as alegrias e as esperanças, as tristezas e as angústias dos discípulos de Cristo; não há realidade alguma verdadeiramente humana que não encontre eco no seu coração (GS 1).

Compadecer-se, deixar-se afetar pela dor do outro. "Misericórdia quero, não sacrifício" (Mt 9,13). Não basta refletir sobre o sofrimento, é preciso identificar-se ativamente com o sofredor. Uma compaixão indignada capacita a identificar a dissonância entre a dor do pobre e a vontade de Deus, assunto da teologia. 


\section{"Ninguém pode sentir-se exonerado da preocupação pelos pobres e pela justiça social" (EG 201)}

Aquilo que motiva a práxis se aplica à reflexão. O Reino de Deus e o sofrimento dos abandonados faz do discurso teológico uma práxis dissidente. O Deus dos descartados exige da teologia a abraçar Sua causa na causa dos pobres. Sua realidade clama por uma teologia subversiva e perigosa à ordem estabelecida. Se o Reino acontece onde se combate o sofrimento, a teologia se faz ouvindo os clamores dos sofredores. Estar ao lado dos abandonados à própria sorte constitui um posicionamento epistêmico. A realidade do sofrimento é um lugar teologal\teológico fundamental que desmascara a verdade de uma realidade ocultada pelo sistema. Os sofredores oferecem um lugar privilegiado para compreender o mundo. Num mundo que vive de aparências e superficialidades, a teologia tem a tarefa de mostrar ao mundo que o sofrimento existe.

A teologia cristã brotou do mistério de um Deus encarnado, traído, torturado e crucificado. O teólogo vive em um mundo marcado pela injustiça, sofrimento e morte. Num sistema apoiado no materialismo é preciso discernir a passagem de Deus, ou os Sinais dos tempos de que fala o Concílio Vaticano II (cf. GS 4.11). A tarefa é mais ampla do que limitar-se a buscar soluções políticas para modelos econômicos fracassados. O sofrimento leva a entender toda a realidade e a história de forma distinta. A teologia pode ter duas posturas: racionalizar o sofrimento com diversas justificativas, levando à insensibilidade com os sofredores. Ou responsabilizar-se, assumindo as dores de quem sofre. Esta postura impede a fuga da realidade oferecidas pelas respostas prontas. A superação do sofrimento revela o significado da salvação na história. Deus abraça o sofrimento humano em Cristo.

Qual é a esperança que a teologia oferece aos sofredores e vítimas da história? A existência do sofrimento imposto aos inocentes tem a ver com Deus que, ao estabelecer o Reino, porá fim aos sofrimentos dos pobres e à falsa satisfação dos ricos. A razão última da salvação ou de condenação definitiva repousa naquilo que se faz ou se deixa de fazer a eles (cf. Mt 25,31-46). Buscar a salvação por outro caminho é erro dogmático.

A realidade do sofrimento arrasta ao compromisso ético com quem sofre a fim de ajudá-lo libertar-se da dor. "O discurso sobre Deus somente 
pode ser universal, isto é, significativo para todos os seres humanos, se expressa em seu núcleo um discurso sobre um Deus sensível e misericordioso diante do sofrimento do outro", afirma Metz (2002, p. 27). O sofrimento aparece como lugar onde se pode conhecer algo do mistério de Deus. A cruz de Jesus é o símbolo de protesto e denúncia do pecado dos responsáveis pelo sofrimento imposto aos inocentes. A dor não é a última palavra da história. O Evangelho não é mensagem de resignação. "Ouro e prata não tenho. Mas o que tenho te dou. Em nome de Jesus Cristo, o nazareno, caminha!" (At 3,6). Trata-se de recuperar o potencial subversivo da fé que desperte os cristãos para seu compromisso com a justiça.

\section{Mysterium iniquitatis: consequências ético-sociais}

A teologia está informada pela dimensão profética da fé. O compromisso com os sofredores leva a identificar os mecanismos geradores de sofrimento imposto às vítimas. "Este sistema social e econômico é injusto na sua raiz" (EG 59). Identificar, compreender e contribuir na superação do mal que sustenta sistemas violentos.

A teologia não é um conjunto de verdades atemporais. No atual contexto a imensa maioria da humanidade vive não só em pobreza, mas, em muitos casos, na absoluta miséria e abandono. Esta realidade é, em grande parte, resultado de uma injustiça estruturada em instituições e seus mecanismos. Este mal radical é definido pela teologia como pecado do mundo (cf. Jo 1,29). Um mal por excelência gerador de outros males. Nenhum outro representa mais a negação de Deus do que esse. As raízes geradoras de sofrimento são sócioestruturais. As míseras condições em que milhões de seres humanos estão condenados são resultado de mecanismos estruturais. O sistema que produz a injustiça deve ser desmascarado para que o esforço na construção de uma sociedade justa seja efetivo.

A ética cristã consiste em aderir a uma pessoa que combateu os pecados do mundo. Os cristãos têm em Jesus Cristo seu referencial na superação das raízes mais profundas da maldade, plasmadas em estruturas de pecado. A lógica da exclusão gera milhões de crucificados pelo sofrimento, que se identificam com Jesus que assumiu a cruz como 
símbolo da nova Aliança de Deus com a humanidade. A teologia deve tomar a sério os povos crucificados para falar da salvação.

Somente a teologia pode revelar a dimensão estrutural do pecado. Somente Deus pode revelar até que ponto sua obra é destruída por mãos humanas. O reconhecimento de que a estrutura é de pecado se dá diante de Deus e do outro. O pecador nega o outro, nega a Deus e se totaliza ao crer não haver outro deus além dele mesmo. Seu ponto de referência é a alteridade. $\mathrm{Na}$ origem da injustiça e da violência a teologia identifica o pecado da ruptura de amizade com Deus e com o próximo.

Gustavo Gutiérrez tem uma contribuição fundamental ao historicizar o processo de salvação (GUTIÉRREZ, 1977; 1980). O autor rompe com o transcendentalismo que impedia que se observassem concretamente os problemas sociopolíticos estruturais. $\mathrm{O}$ pecado deixa de ser compreendido como um mal metafísico, passando a ser conceituado de maneira concreta que ocorre em situações históricas. Há uma violência institucionalizada, um sistema social construído e consolidado sobre a morte do pobre. "O pecado prolifera em estruturas opressoras, na dominação e no espólio de povos, raças e classes sociais" (GUTIÉRREZ, 1980, p. 130). Fatores históricos conduziram a tal situação. As estruturas de pecado não aparecem do nada. Por um lado, não se trata de um ato individual, pois diz respeito às relações sociais pautadas na injustiça. Por outro, o pecado não se restringe às relações pessoais, pois está institucionalizado. Existem forças, atitudes e ideologias opostas ao Reino de Deus entre as quais, duas se destacam: a obsessão pela ganância e o desejo insaciável pelo poder. Ambas buscadas a qualquer preço (cf. SRS 36-37). Seus mecanismos perversos as fazem funcionar contra o bem comum e contra o Reino de Deus.

Todo sistema injusto deve ser confrontado em sua totalidade. As estruturas de pecado são geradas pelo pecado, geradoras de novos pecados, mantenedoras de uma situação de pecado, introduzem as pessoas em uma situação de pecado.

O sistema atual traz o pecado fundamental da idolatria. A Tradição Paulina aponta como a idolatria se oculta na opressão da verdade e na injustiça, cujas consequências desembocam em atitudes externas que desumanizam o próximo: perversidade, injustiça, ganância, maldade, 
assassinato (cf. Rm 1,18ss). Contudo, a mais perigosa das práticas é a avareza, uma vez que "a raiz de todo mal é a busca do dinheiro" (1Tm $6,10)$. As agressões mais cruéis contra a dignidade humana vêm do poder e do dinheiro. O Documento de Aparecida denuncia a idolatria do dinheiro como causa primeira da deterioração da vida social e da violência na América Latina e no Caribe (cf. CELAM, 2007, n. 78). Papa Francisco ensina que "onde há idolatria, apagam-se Deus e a dignidade do ser humano. A obsessão de explorar tudo ao máximo leva a coisificação do outro” (EG 57).

\section{Combater o bom combate $(2 \mathrm{Tm} 4,7)$}

Não há como refletir sobre a experiência de Deus nem combater o sofrimento do indefeso sem confrontar o poder da idolatria do capital. A teologia é convocada pelos descartados a desmascarar as pretensões idolátricas do capital que nega a primazia do ser humano. O discurso sobre Deus revelado em Jesus Cristo é o ponto de apoio mais eficaz na luta contra a idolatria e suas consequências sobre a vida no planeta. Todo sistema alicerçado na injustiça contém elementos idolátricos (cf. ASSMANN; HINKELAMMERT, 1989). É preciso descartar qualquer forma de resignação às suas práticas e ideologias. A teologia não pode desentender-se dos flagelos humanos causados por seus mecanismos perversos. "Ai daquele que constrói seu palácio desprezando a justiça, e amontoa seus andares às custas do direito; que obriga os outros a trabalhar de graça. Só tens olhos e coração para o lucro, para derramar sangue do inocente, para agir com brutalidade e selvageria” (Jr 22,13.17).

A perspectiva teológica do pecado desvela o problema ético das estruturas. Relacionar o pecado com a liberdade significa afirmar que sua origem está na pessoa. A liberdade pessoal também tem parcelas de responsabilidade. O pecado estrutural não é um pecado sem pecador. Pessoas e grupos são corresponsáveis de vários modos, seja pela introjeção, reprodução ou por omissão. A reprodução se concretiza na medida em que se assumem os valores ditados pelas estruturas. A omissão significa cruzar os braços. O que está em jogo não é apenas o destino da pessoa, mas o destino da humanidade e de toda a criação. 
A compreensão tradicional acentuou uma interpretação despolitizada e individualista do pecado. A ética quer recuperar a dimensão política das decisões tomadas na esfera pública. As estruturas de pecado pedem uma interpretação política do mal presente no mundo. Um pecado desprovido da sua dimensão ético-social não desperta para uma mudança de estruturas violentas. O pecado não é um mal abstrato e socialmente inofensivo, mas está relacionado diretamente às liberdades concretas que ferem liberdades concretas. Esta responsabilização pessoal pode ser entendida em sentido individualista ou em sentido comunitário/ político. Não se entende um sem o outro. Não há como escapar da responsabilização das injustiças sociais. A interpretação ético-política descobre a presença do pecado sob muitas formas. Pode ser verificado na política, na economia, na cultura, nas instituições do judiciário, na religião, na educação, na mídia. A desprivatização da noção de pecado é uma tarefa inadiável. Diante da existência de tantas concretizações históricas do pecado, a dimensão ética da fé é extremamente significativa.

\section{Fermento na massa (Lc 13,21): A ética desenvolve a essência do cristianismo}

A fé cristã - quando intensamente vivida como serviço do Reino, que se realiza no seguimento de Jesus sob impulso do Espírito - possui uma incidência ético-social. Não há separação entre teologia sistemática e ética teológica. A dimensão ético-social brota do núcleo do mistério da revelação. Seu ponto de partida não é uma doutrina moral, uma tradição posterior ou uma categoria filosófica. A ética explicitada está arraigada no evento Cristo e as testemunhas. A lex orandi e a lex credendi geram e dinamizam a lex agendi no seio da sociedade (GIRAUDO, 2003, p. 13-19).

A práxis cristã e a oração constituem a teologia primeira e o trabalho dos teólogos é a teologia segunda. Esta articulação entre o litúrgico, o teológico e ético-social acontece na história, aqui e agora. Não há "história sagrada" e "história profana", como se uma pudesse ser compreensível sem a outra. A ação de Deus e a ação humana não são a mesma, mas ambas acontecem no interior de uma única história. A práxis possibilita 
a articulação do conceito teológico salvação ao conceito sociopolítico libertação. Ambos são discursos distintos de uma mesma práxis.

O Reino de Deus irrompe misteriosamente na sociedade e na história através da lex agendi. Não há contradição entre a liberdade cristã e os distintos processos de autêntica humanização e libertação históricas. A ação de Cristo celebrada na Eucaristia não suprime a responsabilidade humana com os rumos da sociedade. A libertação da escravidão do pecado reivindica a libertação das escravidões históricas de ordem cultural, econômica e política, pois as mesmas são obstáculos que impedem à pessoa viver de acordo com sua dignidade enraizada na imagem e semelhança de Deus. Todo autêntico processo de libertação é um sinal incompleto, temporal, da libertação plena oferecida em Cristo. A dimensão soteriológica contém uma dimensão ética.

A experiência de Deus é inseparável das relações sociais. A resposta dos abandonados ao próprio sofrimento não exige nenhum discurso, apenas compaixão. Vide parábola do bom samaritano (cf. Lc 10,30-37). A ética precede à teologia e é mais importante que as orações.

Os abandonados oferecem a possibilidade para que a teologia não se feche em si mesma. Quanto mais o teólogo se aproxima dos abandonados, mais sua teologia é cristã por excelência. Sua reflexão é como consequência da sua libertação de um teologismo inútil que não serve para nada, a não ser alimentar seu próprio ego. O apelo de Deus nunca perde atualidade. "Escutai o clamor de meu povo" (Ex 3,7). "Meu Deus, meu Deus, porque me abandonaste?" (Mc 15,34). O teólogo é um servidor deste indefeso, nu e que grita de desespero. O pacto com eles é prova de sua fidelidade ao Reino de Deus.

Esta lex agendi confere densidade teologal ao compromisso sociopolítico dos cristãos. Como cidadãos, fazem parte da comunidade política. Tradições religiosas como o Cristianismo podem servir de inspiração para uma ética civil. Aqui está uma característica fundamental da lex agendi. A interlocução da teologia com os poderes públicos em vista do bem comum, da defesa da dignidade humana da justiça social se dá a partir das reivindicações dos abandonados. Como ensina Papa Francisco: "Embora a justa ordem da sociedade e do Estado seja dever central da Política, a Igreja não pode nem deve ficar à margem na luta pela justiça” (EG 183). 
A justa ordem da sociedade e do Estado é dever central da política. Vale insistir que teologia não se move por interesses políticos e ideológicos. Sua dimensão ético-social extrapola projetos históricos e circunstanciais. "A Igreja que, em razão da sua missão e competência, de modo algum se confunde com a sociedade nem está ligada a qualquer sistema político determinado" (GS 76). O Evento Cristo contém uma dimensão escatológica que o agir humano na história é incapaz de abarcar totalmente. Portanto, "o Cristianismo é sempre subversivo diante das estruturas de poder. O Reino de Deus não pode ser confundido com um reducionismo político da fé" (GASDA, 2015, p. 217).

\section{Considerações finais}

A abordagem de aspectos imprenscindíveis da perspectiva éticosocial da teologia remete ao núcleo da Revelação. É fundamental que o Cristianismo mantenha-se como instância crítica de uma sociedade estruturada na injustiça e na violência. Nos dias atuais, seu conteudo é substancialmente anti-sistêmico.

Uma teologia cristã desprovida da dimensão ético-social não encontra justificação alguma na Revelação. A cruz de Jesus está plantada fora dos muros como escândalo político e loucura para os defensores da ordem social, mas como esperança para os abandonas ao sofrimento. Estes últimos desmascaram a iniquidade dos primeiros.

Para ser útil ao anúncio do Reino de Deus, a teologia jamais pode prestar-se a alimentar mentalidades individualistas, proselitistas, pietistas ou moralizantes. Estas expressões de infidelidade ao Evangelho seriam mostras, ainda que indiretas, de cumplicidade com as estruturas de pecado. Mais do que uma aberração, seria uma heresia, porque a existência da teologia cristã se deve à Memória de um sofredor subversivo. A salvação é fruto de um Rejeitado pelos poderes deste mundo. No patíbulo escandaloso, que mais pareceu o fim da história, ocorreu a revelação plena e definitiva daquele Deus que os cristãos identificam como Salvador da humanidade.

Fazer de um Descartado o centro das atenções, implica, obrigatoriamente, agir para que todos os abandonados da terra ocupem os 
primeiros lugares no coração, no pensamento e na identidade da teologia. Negar seu eminente protagonismo seria uma heresia. Desconsiderar, ignorar ou manipular essa verdade de fé é pretender reescrever o Evangelho para expulsar Deus da história. O resultado seria a produção de uma teologia materialista, ou, no sentido cristão da palavra, ateia e anticristã, absolutamente inútil para o Reino de Deus.

Diante de situações de sofrimento dos mais desamparados, a teologia muitas vezes optou pelo silêncio. Há silêncios mais eloquentes que discursos. Pior que o silêncio é a legitimação. Pior que a legitimação, a colaboração. Na fidelidade aos abandonados, a teologia põe em cheque sua fidelidade a Cristo. Ela será julgada pela maneira como reage diante de um Deus que identifica-se com o faminto, o sedento, o desnudo, o estrangeiro, o prisioneiro, o enfermo (cf. Mt 25,31-46). Para encontrar-se com Cristo em sua teologia, o teólogo deveria encontrá-lo também nos abandonados, vigários de Cristo!

Se a dimensão ético-social não for devidamente explicitada, corre-se o risco de desfigurar o sentido integral do anuncio do Evangelho. Lex orandi, lex credendi e lex agendi são aspectos de uma mesma fé no Cristo. A teologia não existe em função de si mesma. A dimensão ético-social torna a teologia relevante para a Igreja e para uma sociedade angustiada em sair da loucura do capitalismo.

\section{Referências}

ASSMANN, H.; HINKELAMMERT, F. J. A idolatria do mercado. Petrópolis: Vozes, 1989. BENTO XVI. Carta Encíclica Deus caritas est [DCE]. Roma: Tipografia Vaticana, 2005. BURITICA ZULUAGA, D. El concepto de persona humana en la tradición cristiana y su progresión hasta el personalismo. Cuestiones Teológicas, Medellín, v. 41, n. 96, p. 467-493, 2014.

BOFF, C. Theology and Praxis: Epistemological Foundations. Maryknoll: Orbis Books, 1987. 
GASDA, E. E.

CONCÍLIO VATICANO II. Gaudium et spes [GS]. Constituição pastoral sobre a Igreja no mundo contemporâneo. Roma: Tipografia Vaticana, 1965.

CONFERENCIA EPISCOPAL LATINO-AMERICANA [CELAM]. Documento de Aparecida. Conclusões da V Conferência Geral do Episcopado Latino-americano. Brasília; São Paulo: [s.n.], 2007.

FRANCISCO. Exortação Apostólica Evangelii Gaudium [EG]. Roma: Tipografía Vaticana, 2013.

FRANCISCO. Carta Encíclica Laudato si’: sobre o cuidado da casa comum, 2015. Roma: Tipografía Vaticana, 2015.

GASDA, E. Política, Cristianismo elaicidade. Perspectiva Teológica, Belo Horizonte, v. 47, 2015, n. 132, p. 203-220, 2015.

GASDA, E. Cristianismo e economia. Repensar o trabalho além do capitalismo. São Paulo: Paulinas, 2014.

GIRAUDO, C. Num só corpo: tratado mistagógico sobre a Eucaristia. São Paulo: Loyola, 2003.

GUTIÉRREZ, G. Evangelho e Práxis de Libertação. In: INSTITUTO FE Y SECULARIDADE. Fé Cristã e Transformação Social na América Latina. Petrópolis: Vozes, 1977.

GUTIÉRREZ, G. Pobres e Libertação em Puebla. São Paulo: Paulinas, 1980.

HORSLEY, R. A. Jesus e o Império. O Reino de Deus e a nova desordem mundial. São Paulo: Paulus, 2004.

JOÃO PAULO II. Carta Encíclica Sollicitudo rei socialis [SRS]. Roma: Tipografia Vaticana, 1987.

METZ, J. B. O problema de uma teologia política e a determinação da Igreja como instituição de liberdade crítico-social. Concilium, Petrópolis, n. 6, p. 5-20, 1968.

METZ, J. B. Cómo hablar de Dios frente a la historia de sufrimiento del mundo. Selecciones de teología, Barcelona, v. 33, n. 139, p. 99-106, 1994. Publicação original: Die Rede von Gott angesichts der Leidengeschichte der Welt. Stimmen der Zeit, v. 210, p. 311-320, 1992. 
METZ, J. B. La compasión. Un programa universal del cristianismo en la época de pluralismo cultural y religioso. Revista Latinoamericana de Teología, v. 19, n. 55, p. 25-32, 2002.

MOUNIER, E. O personalismo. São Paulo: Centauro Editora, 2004.

SCHOTTROFF, W. Recordar (zkr). In: JENNI, E; WESTERMANN, C. (eds.). Diccionario teológico manual del Antiguo Testamento. Madrid: Cristiandad, 1978. v. I, p. 710-724.

TRACY, D. The analogical imagination: Christian theology and the culture of Pluralism. New York: The Crossroad Publishing Company, 1981.

Recebido: 15/05/2018

Received: 05/15/2018

Aprovado: 30/07/2018 Approved: 07/30/2018 